\title{
Potentials of Children's Literature in Class
}

\section{Agustín Reyes-Torres, Luis S. Villacañas-de-Castro \& Betlem Soler-Pardo, eds. 2014. Thinking through Children's Literature in the Classroom. Newcastle} upon Tyne: Cambridge Scholars Publishing. 206 pp. ISBN 978-1-4438-5336-1

DOI: 10.21066/carcl.libri.2016-05(02).0016

Edited by Agustín Reyes-Torres, Luis S. Villacañas-de-Castro and Betlem SolerPardo, faculty members of the Language and Literature Education Department at the Universitat de València, Thinking through Children's Literature in the Classroom is a collection of research papers which addresses a variety of issues concerning children's reading and education. It explores, both theoretically and practically, the boundaries of teaching, education and children's literature, and, as the editors state in the introduction, "is the result of understanding literature as a central part of children's education" (1). The volume is divided into five sections, and altogether contains twelve chapters. Each section emphasises different aspects, but the editors present them in a logical sequence and also ensure the quality of all the contributions, making the collection meaningful and interesting for everyone concerned with children's and young adult literature, as well as foreign language teaching.

Section One, "Thinking Theoretically", consists of two papers which explore the relations between teaching, education and children's literature. In the first chapter, Luis S. Villacañas de Castro examines the role of literature in the concept of "education to reality", a term coined by Freud. The author defends "the need for reality to return to the curricula" (11) and gives a number of examples of how literature can help students recognise and understand basic scientific concepts and social realities, which can equip them with the knowledge and opportunity to transform the world around them. In the second chapter, Xavier Mínguez argues that children's literature is undeniably educational "to the same extent that general literature is educational" (31) and that, rather than focus on social or moral values when teaching literature, teachers should emphasise literary values. The enjoyment of reading should be the most important function of children's and young adult literature.

Section Two, entitled “Thinking Literary Competence”, starts with a chapter by Agustín Reyes-Torres in which he cites different authors, such as Bakhtin, Vygotsky and Culler, to explain literary competence and to present it as the ultimate goal of literacy education. He discusses how teachers should reflect on their own teaching in order to provide students with opportunities to think critically and make their own conclusions. Josep Ballester, the author of the next chapter, examines literature as "a space of reflection through the voices of its various characters, but also from its most significant silences and absences" (61). He states that literature and books have enabled humans to transcend "all possible coordinates: time, space, ideology and material. So by reading the experience can be extended forever" (56). The growth of migration, according to the author, is the most important challenge facing education today, and literature can contribute to creating a dialogue between cultures and diversity in the classroom.

"Thinking Teaching Practice" is the title of the third section in which the authors analyse the use of children's literature in different classroom contexts and present a variety of 
meaningful activities. In “'Dragons Be Here': Teaching Children's Literature and Creative Writing with the Help of Maps", Björn Sundmark states that maps in children's books are an unusually under-researched area. He views them as rich iconotexts that "have the potential of making readers into mapmakers and storytellers themselves" (65). With examples such as Stevenson's Treasure Island, Tolkien's The Hobbit, Swift's Gulliver's Travels and Lewis' Narnia, the author highlights three basic functions of maps in children's books: they can be an integral part of the story, a plot guide, or can serve as a means to create a setting. Finally, he illustrates how map-making can be used as a tool for creative writing. Poetry and its educational potential are the subject matter of Maria Luisa Alonso's chapter. She identifies the causes of the neglect of poetry in the academic field of children's literature in its hybrid and varied nature, as well as the fact that "[b]oth childhood and poetry are social constructs and, as such, they are not static concepts" (79). She thoroughly presents and discusses the objectives of using children's poetry in an ESL (English as a Second Language) classroom and gives a number of examples and guidelines that educators will find useful.

The next section, "Thinking Children's Literature in EFL", encompasses three chapters that address the challenge of integrating children's and young adult literature in the specific context of the EFL (English as a Foreign Language) classroom. Elena Ortells' contribution focuses on the introduction of young adult literature in the EFL secondary school and how it offers a wide range of educational possibilities while also serving "as a medium to provide our students with the critical apparatus to question the established system" (97). Stories as an invaluable tool for teaching English from an early age are the focus of Rowena Coles' chapter, which presents a study aimed at early education levels. As part of this study, Oscar Wilde's "The Selfish Giant" (1888) was analysed by university students, and then taken into the classroom and a kindergarten group, in an appropriate form, and shared with children through various engaging activities. The last chapter in this section, written by Tzina Kalogirou and Konstantinos Malafantis, introduces literary works such as The Red Tree, a picturebook by Shaun Tan (2001), and the surrealist poem "The Light-Tree" by Odysseus Elytis (1971), which were read and discussed by students training to become teachers. They were encouraged to become critically conscious readers, since "literature in general has a potential liberating effect in the lives of our students, generating change within them. Literature can inspire students to negotiate the present and anticipate tomorrow" (143).

The last section in the collection, "Thinking Children's Literature in Society" aims to show interdependence between children's literature and other spheres of culture. Gemma Lluch opens her chapter with these questions: "What happens when relevant books for children and young adults in English reach the literary trail in Catalan? How are these books adapted? What do they represent? What changes do they create in the target culture?" (150). To find the answers, she proceeds to analyse the following popular titles of young adult literature: Alice's Adventures in Wonderland, George's Marvellous Medicine, Harry Potter, and The Hunger Games. In the next chapter, written by Betlem Soler Pardo and Beatriz Martín, two film adaptations of one of the most popular fairy tales, "Snow White", were used as a didactic tool in the secondary ELF classroom. The films enhanced students' motivation and interest in literature, and improved their language skills. The last chapter in the book, “'And Her Step-Mother Organized the Wedding': How Violence and Inequalities 
in the Grimms' Collection Can Foster Social Integrative Behaviours in Children”, penned by María Alcantud Díaz, considers reading literature, particularly fairy tales, in light of key competences for lifelong learning suggested by the European Union.

As the editors state in the introduction, all twelve chapters share the goal of materialising the full potential that is set off when children's literature takes the central place within the educational endeavour. A variety of perspectives and ideas is included and elaborated by scholars from across Europe: Spain, England, Italy, Sweden and Greece. All the contributions are well referenced and some of them contain illustrations, charts and pictures, as well as questions that can trigger discussion and serve as starting points for further research. This book offers a fresh and inspiring view of some key concepts in the study of children's literature and language teaching, and introduces major trends and innovations that characterise it. This engaging and useful collection is of interest not only to scholars, teachers, teacher trainees, but also to both the general public and academic readers interested in this field of study.

Dina Alexandra Pavković

\section{Neue Einblicke in die Produktion der russischen Exilkinderliteratur}

Nadia Preindl. 2016. Russische Kinderliteratur im europäischen Exil der Zwischenkriegszeit. Frankfurt am Main-Bern-Bruxelles-New York-Oxford, Warszawa-Wien: Peter Lang (Russian Culture in Europe 11). 278 Seiten. ISBN 978-3-631-67020-0 (Print). 978-3-653-06179-6 (E-Book). DOI 10.3726/978-3653-06179-6

DOI: 10.21066/carcl.libri.2016-05(02).0017

Der vorliegende Band ist die überarbeitete Fassung von Nadia Preindls 2014 am Institut für Slawistik der Universität Wien bei Fedor Poljakov eingereichter Dissertation „Russische Kinderliteratur im europäischen Exil zwischen 1918 und 1939“. Die Monographie bietet nach einer Einführung zu Forschungslage, literaturgeschichtlichem Kontext und Kindheit im Exil mit Schwerpunkt auf der Rolle des Kinderbuches zunächst eine Beschreibung und Typologisierung der (vielgestaltigen) Quellen, gefolgt von theoretischen Diskussionen zu Kinderliteratur im Spiegel pädagogischer und literarischer Kritik, und wird stimmig abgeschlossen mit vier Einzelanalysen. Das breite Resümee ist dreisprachig (deutsch, russisch und englisch). Dazu tritt ein reiches, nach Publikationsformen gegliedertes Quellenkorpus inklusive zahlreicher Abbildungen von Titelblättern und dergleichen mehr, die eindrucksvoll die künstlerische Hochwertigkeit und liebevolle Gestaltung der Veröffentlichungen zeigen. (Ein kleines Manko ist, dass corpus bei Preindl durchgehend masculini generis ist - ein Lapsus, der die Rezensentin vielleicht nur aufgrund ihres latinistischen Hintergrundes stört; deren komparatistischer Background sichert der Verfasserin jedoch die Anerkennung für die Kombination von großer Übersicht und Gespür für aussagekräftige Schwerpunktsetzung.) Das Verzeichnis enthält neben Veröffentlichungen, die als kindgerecht eingestuft wurden, ohne Kinder- oder Jugendliteratur zu sein, sämtliche Werke für Kinder und Jugendliche, die in der Zwischenkriegszeit in den Exilzentren Europas, aber auch in Berlin, für den russischen Markt gedruckt wurden. Ein umfangreicher Anhang mit Werkverzeichnissen in 